знания (на примере экспозиции ГИМ и других музеев мира) // Научные реконструкции в современной экспозиционной и образовательной деятельности музеев. М., 2006. С. 7-17.

7. Поляков Т. П. Мифология музейного проектирования, или «Как делать музей?»-2 / Т. П. Поляков; М-во культуры РФ; Акад. переподготовки работников искусства, культуры и туризма; Рос. ин-т культурологи. М., 2003. 456 с.

8. Андреева И. В. Музей не должен ждать, когда общество проявит к нему свой интерес // Музейный вестник. 2009. Вып. 8. С. 9-17.

9. Шола Т. Предмет и особенности музеологии // Muzeum. 1987. № 153. С. 49-53.

10. Розенблюм Е. А. Время и пространство в музейной экспозиции // Музейная экспозиция: теория и практика. Новые сценарии и концепции: сб. науч. тр. М., 1997. C. $108-117$.

\title{
DOI 10.37386/2687-0584-2021-16-183-185
}

УДК 351.853(517)+94(517)

Азамат Айшагуль

Краеведческий музей Баян-Ульгийского аймака, г. Улгий, Монголия

Сохранение историко-культурного наследия регионов Большого Алтая (на примере Баян-Ульгийского аймака Монгольской Народной Республики)

Аннотация. В статье рассмотрены современные методы сохранения объектов историко-культурного наследия, применяемые государственными структурами, музейным и научным сообществом в регионах Монголии. Показано значение международного сотрудничества как эффективной формы выявления, изучения и обеспечения сохранности объектов наследия в регионах Большого Алтая. Ключевые слова: историко-культурное наследие, Большой Алтай, Монголия, петроглифы, музеи.

В наши дни каждая страна бережно относится к объектам историкокультурного наследия, находящимся на ее территории. Во многих странах проводится изучение и восстанавление памятников, различные мероприятия, направленные на их сохранение и продление сроков их использования. Страны стали находить различные способы сохранения объектов наследия и методы финансирования этой работы.

Одной из главных задач деятельности по сохранению историкокультурного наследия Монголии, находящегося в разных концах страны, а также за ее пределами, является регистрация объектов и документирование данных о наследии. Все объекты историко-культурного наследия, находящиеся на территории Монголии, регистрируются в единой информационной государственной базе, указанной в приложении № 1 приказа № 345 министра образования от 2007 г. и в статье 2 Закона о сохранении культурного наследия. 
Важной составляющей программы сохранения недвижимых объектов культурного наследия является ее внедрение в программу дошкольного и школьного образования, активизация просветительской деятельности: издания книг и учебных пособий, создания научно-документальных фильмов, проведения обучения для жителей провинции, направленного на сохранение культурного наследия провинции. Необходима специальная всеобщая политика, направленная на сохранение культурного наследия, воспитания уважения к памятникам и гордости за наследие своей страны.

При проведении органами управления Монголии таких действий, как регистрация и обеспечение сохранности объектов культурного наследия, а также внедрение соотвествующих тем в образовательную систему, создаются условия для работы специальных организаций в сфере сохранения историко-культурного наследия.

В последние годы активно ведутся исследовательские работы по выявлению и изучению памятников совместно отечественными и зарубежными учеными и специалистами музеев, в ходе которых реализуются различные методы сохранения историко-культурного наследия, в частности создания литейных форм и эстампажного копирования объектов, имеющих особую научную и историческую значимость. Для снятия копий и создания литейных форм наскальных рисунков исследователи используют специальную технологию, применяемую в международной практике. Она обеспечивает сохранение копий объектов, исключает полную утрату памятников, так как невозможно предвидеть, кто, когда, каким образом навредит объектам культурного наследия в отдаленных регионах. Так, например, в последнее время каменные статуи стали гибнуть из-за природных бедствий и деятельности браконьеров, продающих их.

Этот метод был применен в ходе совместной российско-монгольской экспедиции 18 июля - 10 августа 2015 г. по изучению петроглифов Монгольского Алтая: Шивээт-Хайрхан и Хар салаа. В задачи участников экспедиции входило продолжение работы археологов и культурологов России, Монголии, Казахстана, Китая и других стран по созданию единой информационной базы петроглифов эпохи бронзы, раннего железного века и тюркского времени трансграничного Алтая, обозначение сосредоточений петроглифических комплексов на всей географической территории четырех стран, объединяющих историческую и культурную составляющую единой истории народов, населявших данный регион в древности. Маршрут экспедиции пролегал по пяти административным районам - сомонам Баян-Ульгийского аймака: Улаанхус, Цэнгэл, Сагсай, Бугат, Толбо. Баян-Ульгийский аймак располо- 
жен в западной Монголии, гранича на севере с Кош-Агачским районом Республики Алтай Российской Федерации, на западе - с Синьцзян-Уйгурским автономным районом (Восточный Туркестан) Китайской Народной Республики. В экспедиции с российской стороны принимали участие старший научный сотрудник Национального музея имени А. В. Анохина С. М. Киреев (г. Горно-Алтайск), директор автономной некоммерческой организаций «Соломенная капитель» Е. Ю. Назаренко (г. Барнаул), волонтер Л. Р. Прутян (г. Краснодар); с монгольсой стороны от Краеведческого музея Баян-Ульгийского аймака - Хүрэнмөрөн Мажек (г. Ульгий). Участники экспедиции обследовали наскальные рисунки указанных пунктов, произвели их фотофиксацию, выполнили несколько десятков эстампажных копий наиболее характерных и выразительных сюжетов эпохи бронзы и ранннего железного века, зафиксировали курганные могильники, керексуры, ритуальные сооружения, этнографические объекты. Экспедиция способствовала совершенствованию методов эстампажного копирования наскальных русунков, пополнению коллекций музеев, установлению более тесного сотрудничество между музеями Баян-Ульгийской аймака Монголии и Национального музея имени А. В. Анохина Республики Алтай Российской Федерации.

Таким образом, объединение усилий государственных структур, музейного и научного сообщества сопредельных государств, направленных на выявление, изучение и сохранение объектов культурного наследия, находящегося на территории регионов Большого Алтая, позволит реализовать главную задачу - сохранение их для потомков.

Azamat Aishagul

Local History Museum of Bayan-Ulgiy aimag, Ulgiy, Mongolia

Preservation of the historical and cultural heritage of the regions of the Greater Altai (Bayan-Ulga Aimag of the Mongolian People's Republic)

Abstract. The article discusses modern methods of preserving objects of historical and cultural heritage used by government agencies, the museum and scientific community in the regions of Mongolia. It is shown the importance of international cooperation as an effective form of identifying, studying and ensuring the preservation of heritage sites in the regions of the Greater Altai. Keywords: historical and cultural heritage, Greater Altai, Mongolia, petroglyphs, museums 